\title{
HUBUNGAN PENGETAHUAN IMS DENGAN KEPUTUSAN WANITA MENJADI PEKERJA SEKSUAL DI KECAMATAN BANJARSARI
}

\author{
Syefira Ayudia Johar \\ Progra Studi Ilmu Kesehatan Masyarakat, Universitas Veteran Bangun Nusantara Sukoharjo \\ Email: syefira48@gmail.com
}

\begin{abstract}
Abstrak
Di Indonesia, jumlah kasus penderita HIV dari tahun 2005 sampai tahun 2017 sebanyak 280.623, dan kasus AIDS sebanyak 102.667. Infeksi HIV dominan terjadi pada heteroseksual sebesar 69,6\%. Di Jawa Tengah, jumlah kasus baru HIV pada tahun 2017 sebanyak 5.425, sedangkan jumlah kasus baru AIDS sebanyak 1.719. Sedangkan Kota Surakarta memiliki kasus HIV kedua tertinggi se-Jawa Tengah setelah Kabupaten Semarang sebesar 38 kasus HIV dan 46 kasus AIDS pada Bulan September 2017. Penelitian ini menggunakan studi analitik observasional, dengan pendekatan desain kasus kontrol (case control) dan analisis chi-square. Subjek adalah wanita pekerja seksual dengan kelompok kasus dan kelompok kontrol (bukan pekerja seksual) di Kecamatan Banjarsari, Surakarta dengan jumlah subjek masing-masing kelompok 100 orang. Variabel dependen adalah keputusan wanita menjadi pekerja seksual dan variabel independen adalah pengetahuan IMS. Keputusan wanita menjadi pekerja seksual berhubungan dan secara statistik signifikan terhadap pengetahuan IMS (OR=0.08; CI 95\%=0.04 hingga 0.16; $\mathrm{p}<<0.001)$. Keputusan wanita menjadi pekerja seksual berhubungan dengan pengetahuan IMS.
\end{abstract}

Kata Kunci : Keputusan Wanita menjadi Pekerja Seksual, Pengetahuan IMS.

\begin{abstract}
In Indonesia, the number of cases of people with HIV from 2005 to 2017 as many as 280,623, and the case of AIDS as much as 102,667. The dominant HIV infection occurred in heterosexual by 69.6\%. In Central Java, the number of new HIV cases in 2017 was 5,425, while the number of new cases of AIDS was 1,719. While the city of Surakarta has the second highest HIV case in Central Java after Semarang district of 38 HIV cases and 46 AIDS cases in September 2017. The study used observational analytical studies, with case control $\neg$ approach and Chi-square analysis. The subject is a sexual worker woman with a case and a control group (not a sexual worker) in the district of Banjarsari, Surakarta with the number of subjects of each group of 100 people. The dependent variable is a woman's decision to be a sexual worker and an independent variable is IMS knowledge. A woman's decision to become a sexual worker is related and statistically significant to IMS knowledge $(O R=0.08 ;$ CI 95\% = 0.04 to 0.16; $p<<0.001)$. Women's decisions become sexual workers in relation to IMS knowledge.
\end{abstract}

Keyword: decision of woman to be sexual worker, IMS knowledge. 


\section{PENDAHULUAN}

Di Indonesia, penanggulangan HIV dan AIDS terdiri atas promosi kesehatan, pencegahan, diagnosis, pengobatan dan rehabilitasi terhadap individu, keluarga, dan masyarakat. Menurut Peraturan Menteri Kesehatan Republik Indonesia Nomor 21 Tahun 2013 Tentang Penanggulangan HIV dan AIDS berupa iklan layanan masyarakat, kampanye penggunaan kondom pada setiap hubungan seks berisiko, promosi kesehatan bagi remaja dan dewasa muda, peningkatan kapasitas dalam promosi pencegahan penyalahgunaan NAPZA, dan penularan HIV kepada tenaga kesehatan, tenaga non kesehatan yang terlatih (Kementerian Kesehatan RI, 2013).

Setiap harinya terdapat 1 juta orang yang mengalami infeksi menular seksual di dunia (World Health Organization, 2016). Salah satu masalah nasional dalam bidang kesehatan adalah upaya menghadapi masalah Infeksi Menular Seksual (IMS), Human Immunodeficiency Virus (HIV) dan Acquired Immune Deficiency Syndrome (AIDS). Saat ini infeksi menular seksual (IMS) kembali mendapat perhatian besar sejak berkembangnya infeksi HIV/AIDS. Infeksi menular seksual (IMS) sampai saat ini masih merupakan masalah kesehatan masyarakat di seluruh dunia. IMS menempati peringkat 10 besar alasan berobat di banyak negara berkembang.

Kelompok risiko tinggi terkena HIV/AIDS yaitu wanita pekerja seksual, pengguna NAPZA suntik, lelaki yang berhubungan seksual dengan lelaki, narapidana, pelaut, dan pekerja di sektor transportasi (UNAIDS, 2017). Pekerja seksual merupakan kelompok yang paling rentan terhadap infeksi HIV dan diyakini menjadi pendorong yang signifikan dari peningkatan kasus baru HIV dan AIDS (Seib et al., 2009).

Di Indonesia, jumlah kasus penderita HIV tahun 2005 sampai 2017 sebanyak 5.425, dan kasus AIDS sebanyak 102.667 kasus. Infeksi HIV dominan terjadi pada heteroseksual sebesar 69,6\%. Di Jawa Tengah, jumlah kasus baru HIV pada tahun 2017 sebanyak 5.425, sedangkan jumlah kasus baru AIDS sebanyak 1.719 (Kementerian Kesehatan RI, 2018). Sedangkan Kota Surakarta memiliki kasus HIV kedua tertinggi se-Jawa Tengah setelah Kabupaten Semarang sebesar 38 kasus HIV dan 46 kasus AIDS pada Bulan September 2017(KPA, 2017).

Wanita pekerja seks (WPS) merupakan salah satu kelompok risiko tinggi terhadap IMS dan HIV dan AIDS. Perkembangan jumlah WPS jalanan cukup sulit untuk diketahui karena mobilitas tempat operasinya sangat luas. Wanita Pekerja Seksual adalah seseorang yang menjual jasanya untuk melakukan hubungan seksual untuk uang (Malakar, 2015). WPS terbagi menjadi dua yaitu langsung dan tidak langsung (Vandepitte, 2006). Hal tersebut terjadi di bisnis hiburan seperti tempat karaoke, bar, salon kecantikan, dan panti pijat.

Transaksi seksual yang berada di Indonesia yang dilakukan oleh wanita pekerja seksual merupakan ilegal. Pada Kitab Undang-Undang Hukum Pidana (KUHP) Pasal 296, "Barang siapa dengan sengaja menyebabkan atau memudahkan perbuatan cabul oleh orang lain dengan orang lain, dan menjadikannya sebagai pencarian atau kebiasaan, diancam dengan pidana penjara paling lama satu tahun empat bulan atau pidana denda paling banyak lima belas ribu rupiah"(Alrianto M, 2015).

Perkiraan jumlah WPS diberbagai daerah di dunia yaitu dari 2,6\% di Asia, 4,3\% di sub-sahara Afrika, dan 7,4\% di Amerika Latin (Eileen et al, 2013). Prevalensi WPS terbanyak adalah kalangan perempuan dewasa (usia 18-49 tahun) (Thein, Aung and McFarland, 2015). Menurut Yayasan Spiritia (2010), di Indonesia jumlah WPS sebanyak 177.200 - 265.000 orang. Jumlah pelanggan mereka jauh lebih banyak yaitu $2.435 .000-3.813 .000$ orang. Tingginya jumlah WPS dapat disebabkan oleh pendidikan yang rendah sehingga mudah terjerumus ke dalam dunia pelacuran (Puspitaningtyas, 2016).

Menurut (Ningrum et al., 2014) menyatakan bahwa faktor yang mempengaruhi remaja perempuan menjadi Pekerja Seks Komersial (PSK) adalah pengaruh pengetahuan remaja tentang infeksi menular seksual

Berdasarkan studi pendahuluan di dapatkan data dari Komisi Penanggulangan AIDS (KPA) Surakarta bahwa jumlah kumulatif angka kejadian HIV/ AIDS dari 2005 sampai September 2017 yaitu 561 orang. Angka kejadian kasus HIV baru berjumlah 39 orang dan kasus AIDS baru berjumlah 46 orang. Berdasarkan pekerjaan yang berisiko menyebabkan HIV/ AIDS adalah wanita pekerja seksual dengan angka kejadian HIV sebesar 102 orang dan AIDS sebesar 53 orang. Jumlah wanita pekerja seksual di Kecamatan Banjarsari yaitu 428 orang. Dari data tersebut, penulis tertarik untuk mengambil penelitian dengan judul, "Hubungan Pengetahuan Infeksi Menular Seksual dengan Keputusan Wanita Menjadi Pekerja Seksual di Kecamatan Banjarsari”.

\section{METODE PENELITIAN Rancangan Penelitian}

Desain studi penelitian ini adalah studi analitik observasional. Pendekatan studi yang digunakan yaitu studi kasus kontrol. 
Lokasi penelitian di daerah Kecamatan Banjarsari, Surakarta. Penelitian dilakukan selama 1 bulan pada bulan November 2018.

Populasi dan Sampel

Populasi dalam penelitian ini adalah populasi kasus yaitu seluruh wanita pekerja seksual di Kecamatan Banjarsari, Surakarta. Populasi kontrol yaitu wanita yang tidak menjadi pekerja seksual di Kecamatan Banjarsari. Pengambilan sampel dalam penelitian ini dengan cara fixed disease sampling.

Kriteria inklusi terdiri dari wanita yang menjadi pekerja seksual di Kecamatan Banjarsari.

Variabel dependen yaitu keputusan wanita menjadi pekerja seksual. Variabel independen yaitu pengetahuan IMS. Definisi operasional pengetahuan IMS adalah segala sesuatu yang diketahui oleh wanita pekerja seksual tentang infeksi menular seksual. Keputusan wanita menjadi pekerja seksual adalah suatu hasil dari proses berpikir seseorang yang membawa pada pemilihan suatu jalur tindakan menjadi wanita pekerja seksual.

Pengumpulan data menggunakan kuesioner. Dilakukan uji validitas dan reliabilitas pada kuesioner.

Analisis Data

Analisis data menggunakan analisis univariat, dan bivariat. Pada analisis bivariat dengan chi-square.

Berdasarkan hasil uji reliabilitas korelasi item-total didapatkan bahwa pada pengukuran variabel pengetahuan IMS, $r$ hitung $\geq 0.20$, serta Cronbach's Alpha $\geq 0.70$, sehingga semua butir pertanyaan dinyatakan reliabel.

\section{HASIL}

Dimensi karakteristik dari 200 subjek dilihat dari umur wanita pekerja seksual $\leq 30$ tahun sebanyak 104 subjek dengan prosentase 52\% dan $>30$ tahun sebanyak 96 subjek dengan prosentase $48 \%$. Pendidikan <SMA sebanyak 120 subjek dengan prosentase $60 \%$ dan $\geq$ SMA sebanyak 80 subjek dengan prosentase $40 \%$. Wanita dengan status perkawinan janda sebanyak 103 subjek dengan prosentase $51.5 \%$ dan kawin sebanyak 97 subjek dengan prosentase $48.5 \%$. Wanita yang memiliki pendapatan perhari $\leq \mathrm{Rp} .50 .000$ sebanyak 23 subjek dengan prosentase $11.5 \%$ dan >Rp. 50.000 sebanyak 177 subjek dengan prosentase $88.5 \%$ (Tabel 1).

\section{Tabel 1. Karakteristik Subjek Penelitian}

\begin{tabular}{|c|c|c|c|}
\hline & Karakteristik & $\mathbf{N}$ & $\%$ \\
\hline \multicolumn{4}{|l|}{ Umur } \\
\hline & $\leq 30$ tahun & 104 & 52 \\
\hline & $>30$ tahun & 96 & 48 \\
\hline
\end{tabular}

Pendidikan

$<$ SMA

120

60

$\geq$ SMA

$80 \quad 40$

Status Perkawinan

Janda

$103 \quad 51.5$

Kawin

$97 \quad 48.5$

Pendapatan Perhari

$\leq$ Rp. 50.000

$>$ Rp. 50.000

$23 \quad 11.5$

$177 \quad 88.5$

Tabel 2. Karakteristik Subjek dengan Usia Menikah Anak

\begin{tabular}{crrrr}
\hline \multirow{2}{*}{ Karakteristik } & \multicolumn{2}{c}{ WPS } & \multicolumn{2}{c}{ Tidak WPS } \\
\cline { 2 - 5 } & n & \% & n & \% \\
\hline Umur & 59 & 59 & 37 & 37 \\
$\leq 30$ & 41 & 41 & 63 & 63 \\
$\quad>30$ & & & & \\
Pendidikan & 47 & 47 & 3 & 3 \\
SD & 49 & 49 & 21 & 21 \\
SMP & 4 & 4 & 76 & 76 \\
SMA & & & & \\
Status Perkawinan & & 19 & 22 & 22 \\
$\quad$ Janda & 19 & 1 & 78 & 78 \\
$\quad$ Kawin & 81 & 81 & & \\
Pendapatan Perhari & & & & \\
$\quad \leq$ Rp. 50.000 & 23 & 23 & 0 & 0 \\
$\quad>$ Rp. 50.000 & 77 & 77 & 100 & 100 \\
\hline
\end{tabular}

Pada Tabel 2 terlihat kelompok kasus terbanyak pada umur $\leq 30$ tahun yaitu sebesar $59 \%$. Pada kelompok kontrol terbanyak pada umur $>30$ tahun yaitu $41 \%$. Kelompok kasus untuk pendidikan terakhir prosentase tertinggi pada jenjang SMP yaitu 49\%. Pada kelompok kontrol prosentase tertinggi pada jenjang SMA yaitu sebesar 76\%. Kelompok kasus untuk status perkawinan prosentase tertinggi janda yaitu sebesar $81 \%$. Kelompok kontrol untuk status perkawinan prosentase tertinggi kawin yaitu 78\%. Kelompok kasus untuk perhari dengan prosentase tertinggi $>$ Rp. 50.000 yaitu sebesar $77 \%$. Pada kelompok kontrol untuk pendapatan perhari dengan prosentase tertinggi $>$ Rp.50.000 yaitu sebesar $100 \%$.

Tabel 3 statistik deskriptif masing - masing variabel antara lain nilai minimum, nilai maksimum, nilai mean dan standart deviasi. Tabel diatas untuk mengukur variabel dengan skala kontinu, baik variabel dependen dan variabel independen. Mean menggambarkan nilai rata - rata, sedangkan standart deviasi (SD) menggambarkan seberapa jauh bervariasinya data. Jika nilai SD yang kecil merupakan indikasi bahwa data representatif.

Tabel 3. Deskripsi Variabel Penelitian

\begin{tabular}{cccccc} 
Variabel & $\mathrm{n}$ & $\begin{array}{c}\text { Mi } \\
\mathrm{n}\end{array}$ & $\begin{array}{c}\text { Mak } \\
\mathrm{s}\end{array}$ & $\begin{array}{c}\text { Mea } \\
\mathrm{n}\end{array}$ & SD \\
\hline
\end{tabular}




\begin{tabular}{lccccc}
\hline Pengetahua & 20 & 5 & 15 & 11.2 & 2.6 \\
n IMS & 0 & & & 9 & 7 \\
\hline
\end{tabular}

Tabel 4. Analisis Bivariat Pengetahuan tentang IMS dengan Keputusan Wanita Menjadi Pekerja Seksual

\begin{tabular}{|c|c|c|c|c|c|c|}
\hline \multirow{3}{*}{ Kategori } & \multicolumn{4}{|c|}{ Keputusan } & \multirow{3}{*}{$\begin{array}{c}\text { OR } 95 \% \\
\text { CI }\end{array}$} & \multirow{3}{*}{$\mathbf{P}$} \\
\hline & \multicolumn{2}{|c|}{ WPS } & \multicolumn{2}{|c|}{$\begin{array}{l}\text { Tidak } \\
\text { WPS }\end{array}$} & & \\
\hline & $\mathbf{n}$ & $\%$ & n & $\%$ & & \\
\hline Rendah & 65 & 83.3 & 13 & 16.7 & 0.08 & $<0.001$ \\
\hline Tinggi & 35 & 28.7 & 87 & 71.3 & $\begin{array}{c}(0.04- \\
0.16)\end{array}$ & \\
\hline
\end{tabular}

Variabel pengetahuan tentang IMS menunjukan bahwa pengetahuan tinggi mengenai IMS memiliki kemungkinan 0.08 kali lebih rendah untuk seorang wanita mengambil keputusan menjadi pekerja seksual. Secara statistik signifikan $(\mathrm{OR}=0.08$; CI 95\% $=0.04$ hingga $0.16, \mathrm{p}<0.001$ ).

Hasil analisis Chi Square untuk mengetahui hubungan pengetahuan IMS dengan keputusan wanita menjadi WPS, didapatkan nilai $\mathrm{p}$ sebesar <0.001. Nilai $\mathrm{p}$ akan bermakna apabila $<0,005$. Oleh karena nilai $\mathrm{p}$ yang didapat dalam penelitian $<0,005$, maka nilai p ini bermakna. Hal ini menunjukkan terdapat hubungan yang bermakna antara pengetahuan IMS dengan keputusan wanita menjadi pekerja seksual.

Pada variabel pengetahuan tentang IMS dapat dijelaskan, bahwa terdapat hubungan dan secara statistik signifikan antara pengetahuan IMS dengan keputusan wanita menjadi pekerja seksual. Wanita dengan tingkat pengetahuan yang tinggi kemungkinan untuk menjadi pekerja seksual lebih rendah dibandingkan wanita dengan pengetahuan yang rendah.

\section{PEMBAHSAN}

\section{Hubungan Pengetahuan IMS dengan Keputusan Wanita menjadi WPS}

Berdasarkan hasil penelitian menunjukkan terdapat hubungan sebesar 0.08 yang secara statistik signifikan antara pengetahuan tentang IMS dengan keputusan wanita menjadi pekerja seksual $(\mathrm{OR}=0.08$; CI $95 \%=0.04$ hingga $0.16, \mathrm{p}<0.001)$. Wanita dengan tingkat pengetahuan yang tinggi kemungkinan untuk menjadi pekerja seksual lebih rendah dibandingkan wanita dengan pengetahuan yang rendah. Penelitian ini merupakan penelitian analitik dengan pendekatan case control, menggunakan fixed disease sampling, sampel 200 responden, dan kuesioner. Penelitian dari (Mamarodia et al., 2017) ini menggunakan pendekatan cross sectional, sampel 97 siswa dengan menggunakan kuesioner. Hasil dari penelitian ini, bahwa pengetahuan berhubungan dengan tindakan pencegahan penyakit menular seksual $(\mathrm{OR}=5.95$; $\mathrm{p}=0.000$ ). Minimnya pengetahuan WPS tentang penyakit menular seksual dan pencegahannya menyebabkan penularan IMS pada WPS masih tetap tinggi. Rendahnya pemahaman yang benar tentang penyakit menular seksual berdampak pada perilaku pencegahan pada kalangan wanita pekerja seks.

Hasil penelitian dari Fatimah (2013), bahwa ada hubungan yang signifikan antara pengetahuan dengan tingkat pencegahan penularan IMS $(\mathrm{p}<0.05)$. penelitian ini menggunakan pendekatan cross sectional, sampel 50 pasien IMS, analisis data dengan menggunakan uji hipotesis chisquare. Menurut pernyataan dari (Lestari, 2010), pengetahuan kesehatan akan berpengaruh terhadap perilaku seseorang. Selanjutnya perilaku kesehatan akan berpengaruh kepada indikator kesehatan seseorang. Seseorang yang memiliki pengetahuan kesehatan tentang IMS yang rendah akan berpengaruh terhadap perilaku kesehatannya seperti halnya melakukan transaksi seksual yang berisiko yang akan meningkatkan penularan IMS. Diharapkan pengetahuan IMS akan berpengaruh pada pengambilan keputusan seseorang untuk tidak bekerja menjadi WPS.

Hal ini sesuai dengan pernyataan Setyani (2016); Regar (2016), bahwa baik tidaknya pemahaman seseorang salah satunya dipengaruhi oleh faktor pendidikan. Selain itu, pendidikan juga mempengaruhi pengetahuan WPS. Semakin tinggi pendidikan seseorang, maka semakin mudah untuk menerima informasi dan semakin banyak pengetahuan yang dimiliki. Berdasarkan fakta nampak bahwa sebagian besar responden memiliki pengetahuan yang rendah, hal ini berarti responden sebenarnya belum memahami tentang infeksi menular seksual. Hal ini didukung dengan latar belakang responden yang mayoritas berpendidikan SMP maka muncul kecenderungan responden sulit memahami informasi yang baru diterimanya. Dengan demikan dapat disimpulkan seseorang yang mempunyai pendidikan tinggi akan semakin banyak menangkap atau memperoleh informasi dan lebih mudah menerima informasi. Sebaliknya seseorang yang mempunyai pendidikan yang kurang tersebut maka dapat menghambat seseorang dalam memperoleh informasi.

Menurut Nurcholis A et al (2018), pendidikan merupakan faktor yang paling kuat mempengaruhi pengetahuan mengenai IMS semakin baik pengetahuan seseorang, maka semakin baik pula praktik pencegahan IMS dan HIV\&AIDS. Pengetahuan seseorang tidak harus didapat dari pendidikan formal saja akan tetapi dapat berupa pendidikan non formal melalui media massa, media elektronik maupun media perorangan seperti 
anjuran atau penyuluhan. Pengetahuan responden tentang IMS dan HIV\&AIDS mempengaruhi persepsi seseorang, dalam hal ini persepsi tentang kerentanan terkena IMS dan HIV\&AIDS.

Berdasarkan penelitian dari Astarini D (2013), pengetahuan seseorang berpengaruh terhadap indikator kesehatan secara tidak langsung. Pengetahuan tersebut akan berpengaruh kepada perilaku, kemudian perilaku kesehatan akan berpengaruh kepada meningkatnya indikator kesehatan masyarakat. Dalam hal ini, pengetahuan yang baik tentang IMS akan meningkatkan perilaku pencegahan IMS yang akan berdampak pada menurunnya pengambilan keputusan menjadi pekerja seksual. Hal ini menggambarkan bahwa tingkat pengetahuan mengenai IMS dapat berpengaruh terhadap keputusan wanita menjadi pekerja seksual.

\section{SIMPULAN}

Terdapat hubungan dan signifikan antara pengetahuan tentang IMS dengan keputusan wanita menjadi pekerja seksual. Wanita dengan tingkat pengetahuan yang tinggi kemungkinan untuk menjadi pekerja seksual lebih rendah dibandingkan wanita dengan pengetahuan yang rendah $(\mathrm{OR}=0.08$; CI 95\%=0.04 hingga 0.16, $\mathrm{p}<0.001$ ).

\section{DAFTAR PUSTAKA}

Alrianto. 2015. Kajian Kriminologi Terhadap Praktek Prostitusi.

Dasgupta, S. (2013) 'Poverty as a contextual factor affecting sexual health behavior among female sex workers in India', Qualitative Health Research, 23(6), pp. 825-833.

Eileen. 2013. HIV/STI Risk Among Venue-Based Female Sex Workers Across The Globe: A Look Back And The Way Forward, 10, pp. 20-24.

Irwansyah, L. (2016) 'Kemiskinan, Keluarga dan Prostitusi pada Remaja', Psychology and Humanity, 2, pp. 19-20.

Kementerian Kesehatan RI (2017) 'Data dan Informasi Profil Kesehatan Indonesia 2016', Kementerian Kesehatan RI, p. 100.
Lestari, D. (2010) 'Pengaruh Pendidikan Kesehatan Terhadap Pengetahuan Sikap dan Perilaku PSK Dalam Rangka Pencegahan IMS di Lokalisasi Gajah Kumpul Kabupaten', Universitas Sebelas Maret Surakarta, Fakultas

Malakar. (2015) 'Hazardous Health Behavior of Female Sex Workers: A Case Study of', 4(8), pp. 55-59.

Mamarodia. (2017) 'Menular Seksual Pada Siswa Di Sma Dharma Wanita Pineleng', pp. 103-113.

Okigbo, C. (2014) 'Risk Factors for Transactional Sex among Young Females in PostConflict Liberia', African Journal of Reproductive HealthAfr J Reprod Health, 18(183), pp. 133-133.

Seib, C. (2009) 'Sexually transmissible infections among sex workers and their clients: Variation in prevalence between sectors of the industry', Sexual Health, 6(1), pp. 4550.

Solomon, M. M., Smith, M. J. and Del Rio, C. (2008) 'Low educational level: a risk factor for sexually transmitted infections among commercial sex workers in Quito, Ecuador', International Journal of STD \& AIDS, 19(4), pp. 264-267.

Thein, S. T., Aung, T. and McFarland, W. (2015) 'Estimation of the Number of Female Sex Workers in Yangon and Mandalay, Myanmar', AIDS and Behavior, pp. 19411947.

UNAIDS (1997) 'Kelompok Berisiko Tinggi', p. 1997.

Vandepitte, J. (2006) 'Estimates of the number of female sex workers in different regions of the world', Sexually Transmitted Infections, p. iii18-iii25.

World Health Organization (no date) 'WHO | Sexually transmitted infections (STIs)', World Health Organization Website.

Wulandari, M. J. (2017) 'Pengaruh Faktor Sosial Ekonomi Rumah Tangga Terhadap Sikap Kesehatan Reproduksi Pada Remaja Fakultas Ekonomi dan Bisnis Universitas Udayana, pp. 1-35 